\title{
The Development Of Learning Technology Based On Character Building With Dick And Carey Model
}

\author{
Noviana Desiningrum, Endang Nuryasana \\ Universitas Wijaya Kusuma Surabaya \\ Surabaya, Indonesia \\ d.noviana1985@gmail.com
}

\author{
Mustaji, Andi Mariono \\ Universitas Negeri Surabaya \\ Surabaya, Indonesia \\ mustaji@unesa.ac.id
}

\begin{abstract}
This research aims to develop teaching materials learning technology by integrating the strengthening of the characters are arranged with the Dick and Carey model. Strengthening the characters are built with the spirit of "Kita BISA". The meaning of "Kita" represents lecturer and students, while "BISA" represents the characters of Bernalar, Intergritas, Santun, Adil. Data collection is done through literature study on several references that are in accordance with the research problem. This research resulted: 1) Model of Student Character Reinforcement Evaluation, and 2) Systematic teaching-learning technology materials consist of 9 chapters: (1) The development, the area and the foundation of the philosophy Learning technology, (2) The theoretical foundation of learning technology and elements of educational technology, (3) Creation and Management, (4) Use and Utilization, (5) Process and Learning Resources, (6) ) Facilitating Learning, (7) Performance Improvement, (8) Professional Ethics and Educational Technology, and (9) Online Learning.
\end{abstract}

Keywords- Teaching technology materials, Character Strengthening.

\section{INTRODUCTION}

Learning is a systematic process in which each component influences each other for the success of students in the learning process. This means that students need to interact with learning resources in achieving learning objectives. To improve the quality of learning, engineering of learning methods that include organizing strategies, delivery strategies, and learning management strategies need to be pursued continuously. The above efforts are done so that learning can take place more effectively, efficiently, have an attraction and be able to motivate students to learn independently. The attractiveness of learning is measured by the tendency of students to continue learning and interest in the courses. On the other hand, the prepared textbook should also be oriented towards vision, faculty and university missions. ie loading the character strengthening. In other words, the textbook produced should contain the strengthening of the characters in each learning process.

Efforts to create an effective, efficient and appealing learning process requires learning resources that can be used and utilized to support better quality learning. The facts on the field show that: (1) Learning Technology is one of the subjects in S1 Program, PGSD Universitas Wijaya Kusuma Surabaya, (2) So far, no lecturer has written teaching-learning technology materials, (3) Low knowledge and understanding of students in studied learning technology lessons, (4) There is no learning resource in the form of teaching-learning technology based on character building. Message from the Minister of Education and Culture of the Republic of Indonesia states that; Strengthening the character of the nation to be one item Nawacita proclaimed President Joko Widodo through the National Movement of the Mental Revolution (GNRM). This commitment is followed up with the direction of the President to the Minister of Education and Culture to prioritize and cultivate character education in the world of education, [1]

Therefore, it is necessary to develop instructional material of learning technology based on the strengthening of character through research procedure. This research was conducted for two factors: 1) The lack of students' competence to understand and apply the learning technology, 2) No researcher has developed teaching-learning technology material that integrates the strengthening of characters compiled [2]

\section{METHOD}

This research is a development research [3] that aims to integrate the strengthening of characters in learning technology materials that are prepared with Dick and Carey model. According to Borg and Gall, there are 10 steps of research and development, that is (1) Research and information collecting, (2) Planning, 3. Develop preliminary form of product, (4) Preliminary field testing, (5) Main product revision, (6) Main field testing, (7) Operational product revision, (8) Operational field testing, (9) Final product revision, (10) Dissemination and implementation. The steps of research and development can be seen in the following figurel.

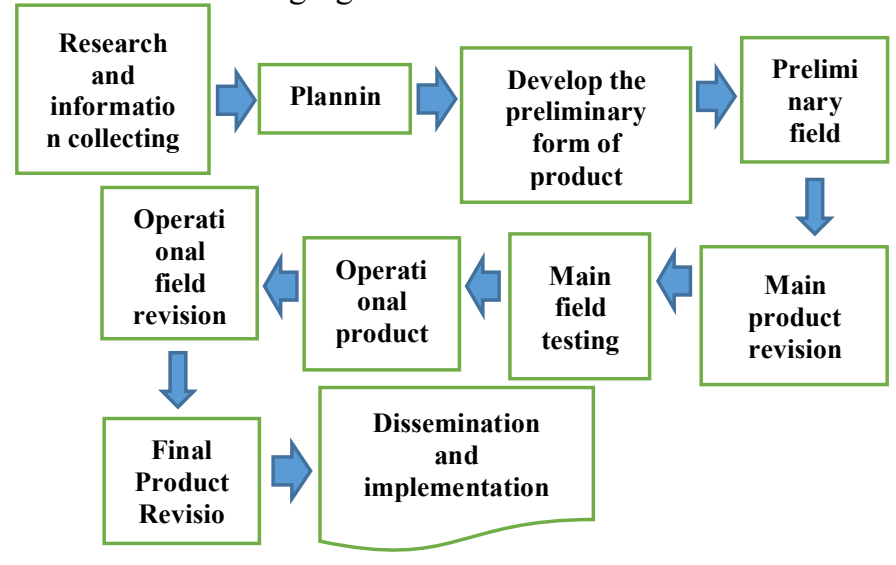

Fig. 1. The R \& D steps used 
One indicator of the success of the learning process is the activity of students in the learning, In order to achieve this success, it is necessary to design a mature learning from the start goal, understand the character of students who will run the learning, determine the appropriate model or strategy, and evaluation. The Dick and Carey learning design model offers a complete design for all the processes already mentioned. In the form of a chart [4]Dick and Carey's teaching design model can be described as follows:

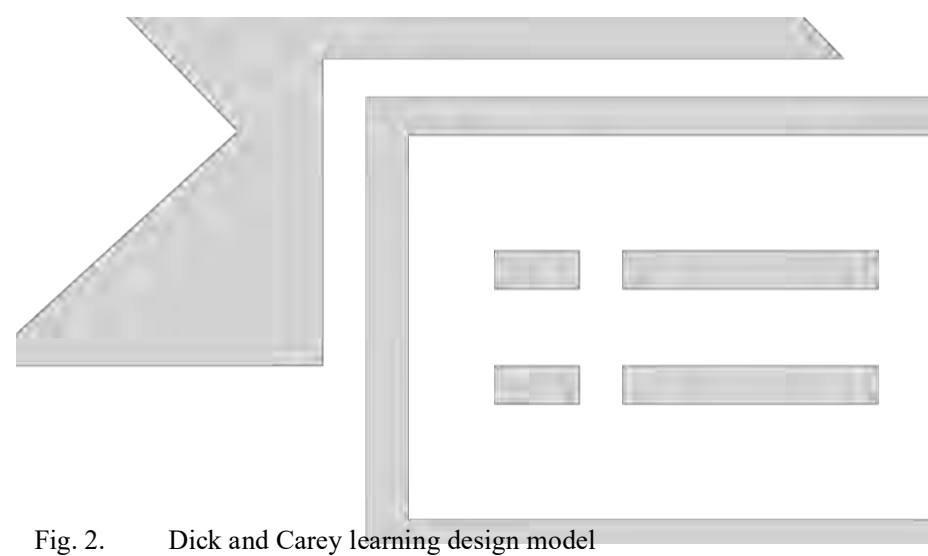

Figure 2. following explanation of the steps of Dick \& Carey research development Model ; (1) Identity Instructional Goals, (2) Conducting Instructional Analysis, (3) Learning and Context Analysis, (4) Formulate Performance Objectives, (5) Develop Assessment Instruments, (6) Develop Instructional Strategy, (7) Develop and Select Instructional Materials, (8) Designing and Conducting Formative Evaluation of Instruction, (9) Perform Instructional Revision, (10) Design and Conduct Summative Evaluation.

[5]Data collection is done through literature studies and analyzes relevant documents and references on theories and concepts: 1) learning technology, 2) aspects of character reinforcement and 3) Dick and Carey model steps. [6]Data were analyzed structured, systematic and integrated to the concept and theory of learning technology, character aspect, and model of Dick and Carey. Strengthening the characters are built with the spirit of "Kita BISA". The meaning of "Kita" represents lecturers and students, while "BISA" represents the character of Bernalar, Integrity, Santun, Adil. Data collection is done through literature study on several references that are in accordance with the research problem. Further integrating character reinforcement in student learning activities.

\section{Result AND Discussion}

This research resulted in 1) Model of Student Character Reinforcement Evaluation, and 2) Systematic teaching-learning technology materials consisting of 9 chapters, namely: (1) The development, the area and the foundation of the philosophy Learning technology, (2) The theoretical foundation of learning technology and elements of educational technology, (3) Creation and Management, (4) Use and Utilization, (5) Process and Learning Resources, (6) ) Facilitating Learning, (7) Performance
Improvement, (8) Professional Ethics and Educational Technology, and (9) Online Learning.

\section{1) Model of Student Character Reinforcement Evaluation.}

Model evaluation of student character strengthening using the Likert scale, with character score: $1=$ Very Less Good, $2=$ Less Good, 3 = Good Enough, $4=$ Good, and $5=$ Very Good. Example of Model evaluation of student character strengthening. Instructions: (1) Circle the number: $1 / 2 / 3 / 4 / 5$ to assess the character of the students raised in the learning activities of students in studying the development, understanding and learning technology area, (2) observation conducted by 3 (three) people; (a) 2 student friends, and (b) 1 (one) lecturer or colleague. Description: $1=$ Very Less Good, 2 = Less Good, 3 = Good Enough, 4 = Good, and $5=$ Very Good.

\section{TABLE I. OBSERVATION OF STUDENT CHARACTER} ASSESSMENT

Lecture Material: Development and Learning Technology Area

\begin{tabular}{|c|c|c|c|}
\hline No & character & Student learning activities & Score \\
\hline 1 & $\begin{array}{l}\text { Reasoning } \\
\text { ("Bernalar") }\end{array}$ & $\begin{array}{l}\text { Discuss understanding of } \\
\text { learning technology since } 1963 \text {, } \\
1972,1977,1994 \text {, and } 2008 \text {. }\end{array}$ & $1 / 2 / 3 / 4 / 5$ \\
\hline 2 & & $\begin{array}{c}\text { Explain definition and different } \\
\text { concept of learning technology in } \\
\text { the years 1963,1972,1977, } \\
1994, \text { and } 2008 .\end{array}$ & $1 / 2 / 3 / 4 / 5$ \\
\hline 3 & & $\begin{array}{c}\text { Explain the figures or } \\
\text { institutions that build the } \\
\text { definition of learning } \\
\text { technology. }\end{array}$ & $1 / 2 / 3 / 4 / 5$ \\
\hline 4 & & $\begin{array}{l}\text { Present the development of } \\
\text { learning technology in the class } \\
\text { by using appropriate media. }\end{array}$ & $1 / 2 / 3 / 4 / 5$ \\
\hline 5 & & $\begin{array}{l}\text { Discussing the understanding, } \\
\text { the kind of area, the different } \\
\text { concepts of each region, the } \\
\text { figures and institutions that } \\
\text { build the definition of learning } \\
\text { technology area. }\end{array}$ & $1 / 2 / 3 / 4 / 5$ \\
\hline 6 & & $\begin{array}{l}\text { Presenting the understanding, } \\
\text { the kind of area, the different } \\
\text { concepts of each region, figures } \\
\text { and institutions that build the } \\
\text { definition of learning } \\
\text { technology area. }\end{array}$ & $1 / 2 / 3 / 4 / 5$ \\
\hline 7 & & $\begin{array}{l}\text { Discusses the application of } \\
\text { each area in the learning } \\
\text { process in the class. }\end{array}$ & $1 / 2 / 3 / 4 / 5$ \\
\hline 8 & & $\begin{array}{l}\text { Present the application of each } \\
\text { area in the learning process in } \\
\text { the class. }\end{array}$ & $1 / 2 / 3 / 4 / 5$ \\
\hline 9 & & $\begin{array}{l}\text { Discusses the benefits of the } \\
\text { learning technology area for } \\
\text { school, teacher, and students. }\end{array}$ & $1 / 2 / 3 / 4 / 5$ \\
\hline 10 & & $\begin{array}{l}\text { Present the benefits of the } \\
\text { learning technology area for } \\
\text { school, teacher, and students. }\end{array}$ & $1 / 2 / 3 / 4 / 5$ \\
\hline 11 & $\begin{array}{c}\text { Integrity } \\
\text { ("Integritas") }\end{array}$ & $\begin{array}{c}\text { Students have the responsibility } \\
\text { of presenting the understanding } \\
\text { of area and learning } \\
\text { technology. }\end{array}$ & $1 / 2 / 3 / 4 / 5$ \\
\hline 12 & & $\begin{array}{l}\text { Students are committed to } \\
\text { presenting the region and } \\
\text { learning technology. }\end{array}$ & $1 / 2 / 3 / 4 / 5$ \\
\hline
\end{tabular}




\begin{tabular}{|c|c|c|c|}
\hline No & character & Student learning activities & Score \\
\hline 13 & & $\begin{array}{l}\text { Students honestly present area } \\
\text { and learning technology. }\end{array}$ & $1 / 2 / 3 / 4 / 5$ \\
\hline 14 & & $\begin{array}{l}\text { Students have the bravery to } \\
\text { present the area and learning } \\
\text { technology. }\end{array}$ & $1 / 2 / 3 / 4 / 5$ \\
\hline 15 & & $\begin{array}{l}\text { Students have tolerance for } \\
\text { delivering the presentation of } \\
\text { area and learning technology. }\end{array}$ & $1 / 2 / 3 / 4 / 5$ \\
\hline 16 & & $\begin{array}{l}\text { Students have the discipline in } \\
\text { carrying the job/task given by } \\
\text { the lecturer. }\end{array}$ & $1 / 2 / 3 / 4 / 5$ \\
\hline 17 & & $\begin{array}{l}\text { Students work hard in learning } \\
\text { to understand the area and } \\
\text { learning technology. }\end{array}$ & $1 / 2 / 3 / 4 / 5$ \\
\hline 18 & & $\begin{array}{l}\text { Students have the attitude of } \\
\text { tolerance and cooperate in the } \\
\text { discussion of the understanding } \\
\text { of the area and learning } \\
\text { technology. }\end{array}$ & $1 / 2 / 3 / 4 / 5$ \\
\hline 19 & $\begin{array}{l}\text { Politeness } \\
\text { ("Sopan/sant } \\
\text { un") }\end{array}$ & $\begin{array}{c}\text { Students are able to } \\
\text { communicate clearly (oral and } \\
\text { written) in the discussion and } \\
\text { present the learning area and } \\
\text { technology. }\end{array}$ & $1 / 2 / 3 / 4 / 5$ \\
\hline 20 & & $\begin{array}{l}\text { Students are able to interact } \\
\text { effectively in discussions and } \\
\text { present learning areas and } \\
\text { technology. }\end{array}$ & $1 / 2 / 3 / 4 / 5$ \\
\hline 21 & & $\begin{array}{l}\text { Students respect the opinions } \\
\text { and suggestions of others in } \\
\text { discussing and presenting area } \\
\text { and learning technology. }\end{array}$ & $1 / 2 / 3 / 4 / 5$ \\
\hline 22 & & $\begin{array}{l}\text { Students Do not say dirty and } \\
\text { abusive in discussions or } \\
\text { present area and learning } \\
\text { technology. }\end{array}$ & $1 / 2 / 3 / 4 / 5$ \\
\hline 23 & & $\begin{array}{l}\text { Students greeting before } \\
\text { discussion and presenting area } \\
\text { and learning technology. }\end{array}$ & $1 / 2 / 3 / 4 / 5$ \\
\hline 24 & & $\begin{array}{l}\text { Students always dress modestly } \\
\text { in the discussion and presenting } \\
\text { area and learning technology. }\end{array}$ & $1 / 2 / 3 / 4 / 5$ \\
\hline 25 & $\begin{array}{l}\text { Fair } \\
\text { (“Adil”) }\end{array}$ & $\begin{array}{l}\text { Students do not discriminate } \\
\text { between friends in discussions } \\
\text { or present area and learning } \\
\text { technology. }\end{array}$ & $1 / 2 / 3 / 4 / 5$ \\
\hline 26 & & $\begin{array}{l}\text { Students do good and help each } \\
\text { other in studying the subject } \\
\text { matter of area and learning } \\
\text { technology. }\end{array}$ & $1 / 2 / 3 / 4 / 5$ \\
\hline 27 & & $\begin{array}{c}\text { Students create a safe, } \\
\text { educative and harmonious to } \\
\text { learn about the subject matter } \\
\text { of the area and learning } \\
\text { technology. }\end{array}$ & $1 / 2 / 3 / 4 / 5$ \\
\hline 28 & & $\begin{array}{l}\text { Students give other groups an } \\
\text { opportunity to respond to the } \\
\text { results of the discussion and } \\
\text { accept them as material for } \\
\text { improvement. }\end{array}$ & $1 / 2 / 3 / 4 / 5$ \\
\hline \multirow{2}{*}{\multicolumn{3}{|c|}{$\begin{array}{c}\text { Score total }(\mathrm{ST}) \\
\text { Average }=\text { score total } / 28\end{array}$}} & ST \\
\hline & & $=$ score total $/ 28$ & $\mathrm{ST} / 28$ \\
\hline
\end{tabular}

Furthermore, the Average Student Character Values (RNKM) is confirmed in Table Category of Student Character. Confirmation is to know the character of students in studying the lecture material. The Table Category of Student Character as follows;

TABLE II. CATEGORY OF STUDENT CHARACTER

\begin{tabular}{|c|c|}
\hline $\begin{array}{c}\text { Average Student } \\
\text { Character Values } \\
\text { (RNKM) }\end{array}$ & Category \\
\hline $1 \leq \mathbf{R N K M}<\mathbf{2}$ & Less Good \\
\hline $2 \leq \mathbf{R N K M}<\mathbf{3}$ & Good Enough \\
\hline $3 \leq \mathbf{R N K M}<\mathbf{4}$ & Good \\
\hline $4 \leq \mathbf{R N K M}<\mathbf{5}$ & Very Good \\
\hline
\end{tabular}

\section{2) Systematic Teaching Learning Technology} Materials.

Systematic teaching-learning technology materials consisting of 9 chapters, namely: (1) The development, the area and the foundation of the philosophy Learning technology, (2) The theoretical foundation of learning technology and elements of educational technology, (3) Creation and Management, (4) Use and Utilization, (5) Process and Learning Resources, (6) Facilitating Learning, (7) Performance Improvement, (8) Professional Ethics and Educational Technology, and (9) Online Learning.

Systematic teaching materials on each Chapter are presented as; (1) General Instructional Objectives, (2) Special Instructional Goals, (3) Lecture Material, (4) Student learning activities, (5) Independent Task, (6) Student Character Assessment, (7) Formative test, and (8) Summative test. This systematics is based on aspects of strengthening the character and the ten steps Dick and Carey model. There are 8 steps in the preparation of this Systematics, which is a modification of the 10 steps Dick and Carey model.

\section{CONCLUSION}

It is not easy to integrate teaching-learning materials based on character-learning that refers to the ten-step model of Dick and Carey. This research aims to produce teaching materials about learning technology whose contents are integrated about the strengthening of characters packed using the formula "Kita Bisa". The meaning of "Kita" represents lecturers and students, while "BISA" is an acronym of the characters Bernalar, Integritas, Santun, and Adil. The developed teaching material is intended for students, lecturers, and observers of education, especially in the field of learning technology.

The development procedure use Dick and Carey model which consists of ten stages: (1) Identity instructional goals, (2) Conduct instructional analysis, (3) Analyze learners and contexts, (4) Write performance objectives, (5) Develop assessment instrument, 6) Develop instructional strategies, (7) Develop and select instructional materials, (8) Design and conduct formative evaluation of instruction, (9) Revise instruction, (10) Design and conduct summative evaluations.

The development procedure use Dick and Carey model which consists of ten stages: (1) Identity instructional goals, (2) 
Conduct instructional analysis, (3) Analyze learners and contexts, (4) Write performance objectives, (5) Develop assessment instrument, 6) Develop instructional strategies, (7) Develop and select instructional materials, (8) Design and conduct formative evaluation of instruction, (9) Revise instruction, (10) Design and conduct summative evaluations. This instructional material consists of nine chapters: (1) Development, area and philosophical foundation Learning technology, (2) Theoretical base of learning technology and elements of educational technology, (3) Creation and Management, (4) Usage, (5) Process and Learning Resources, (6) Facilitating Learning, (7) Performance Improvement, (8) Professional Ethics and Educational Technology, (9) Online Learning and this resource is equipped with glossary and index.

\section{ACKNOWLEDGMENTS}

We are a Team of Researchers of Higher Education Cooperation (PKPT). TPP Chairman Noviana Desiningrum, S.Pd., M.Pd., Member of Dra.Endang Nuryasana, S.Pd., M.Pd. from University Wijaya KUsuma Surabaya. Whereas Chairman of TPM Prof. Dr. Mustaji, M.Pd., with Dr. Andi Mariono, M.Pd., from the University State of Surabaya.

The authors thank Prof. Mustaji and Dr. Andi Mariono from Surabaya State University for advice in the writing of this manuscript.

The authors thank Dra. Endang Nuryasana, M.Pd. form University Wijaya Kusuma Surabaya, my partner this research.

The authors thank the dean of the Faculty of Language and Science of University Wijaya Kusuma Surabaya Dr. Fransisca Dwi Harjanti, M.Pd., which has provided ease and support to conduct research collaboration with the State University of Surabaya

The authors thank my friends of University Wijaya Kusuma Surabaya for the Spirit and encouragement to do research.

The authors would like to thank the Directorate of Research and Community Service, Directorate General Strengthening Research and Development Ministry of Research, Technology and Higher Education for financial support of this experiment under contract No. 008/SP2H/LT/K7/KM/2018 February 26, 2018.

\section{REFERENCES}

[1] K. J. Reivich, M. E. P. Seligman, and S. McBride, "Master resilience training in the US Army.," Am. Psychol., vol. 66, no. 1, p. 25, 2011.

[2] W. Dick, "The Dick and Carey model: Will it survive the decade?," Educ. Technol. Res. Dev., vol. 44, no. 3, pp. 55-63, 1996.

[3] H. P. Setyosari, Metode penelitian pendidikan \& pengembangan. Prenada Media, 2016.

[4] R. C. Richey, D. C. Fields, and M. Foxon, Instructional design competencies: The standards. ERIC, 2001.

[5] A. Januszewski, Educational technology: The development of a concept. Libraries Unlimited, 2001.

[6] P. Saettler, The evolution of American educational technology. IAP, 2004. 